\title{
VALUE PROMOTION AND EUROPEANISATION BY EU TRADE AGREEMENTS
}

\author{
Balazs Horvathy \\ HAS Centre for Social Sciences, Institute for Legal Studies
}

\begin{abstract}
Promoting values of the European Union has been on the EU's external trade agenda since the 1990s. The Treaty of Lisbon established a general framework for values and principles, requiring the Union to pursue these concepts in the whole range of EU external relations, including the Common Commercial Policy (CCP). Therefore, the operation of CCP is governed not only by traderelated concepts such as progressive liberalisation, but it also reflects on non-trade concerns - e.g. protection of human rights, fair trade, or sustainable development - as well. This inclusive character of CCP is anchored also in the new external trade strategy of the European Union ('Trade for all'), which stresses the importance of trade agreements concluded by EU in promotion of values towards third countries. The paper aims at addressing a conceptual and a procedural question related to this context: First, what kind of values of the European Union integrated in trade agreements can lead to the Europeanisation of domestic legal order of the third countries; and second, how these concepts can be implemented, i.e. how the process of Europeanisation is taking place using the example of the human rights promotion.
\end{abstract}

Key words: Europeanisation, Common Commercial Policy, values, human rights

\section{INTRODUCTION}

The Common Commercial Policy (CCP) has become an integral part of the European Union's external action as a result of the Treaty of Lisbon, ${ }^{1}$ which also established a general framework for values, principles and objectives, requiring that the Union shall pursue these concepts in the whole range of the EU external relations. Therefore, the functioning of the CCP is based on a two-level structure of principles and objectives, which encompasses not only the proper, trade-related goals, such as progressive liberalization, but includes several non-trade concerns, like protection of human rights, or promotion of sustainable development as well. At first glance, these changes seem to be unimportant, knowing that the European Union has been committed to implementing an inclusive, 'valuesdriven' trade policy for many decades towards third countries. ${ }^{2}$ This latter process is labelled here as

1 The paper does not address all achievements of the Lisbon Treaty regarding the CCP. For a comprehensive analysis, see BUNGENBERG, M. - HERRMANN, C. (eds.): Common Commercial Policy after Lisbon. In: European Yearbook of International Economic Law, Special issue, 2013; KRAJEWSKI, M.: The Reform of the Common Commercial Policy. In Biondi A. and others (eds.): EU Law after Lisbon. Oxford: Oxford University Press, 2012, pp. 292-311.; DIMOPOULOS, A.: The common commercial policy after Lisbon: Establishing parallelism between internal and external economic relations? In: Croatian Yearbook of European Law and Policy, 2008/4, pp. 101-129.; MARISE, C.: Balancing Union and Member State interests: Opinion 1/2008, Choice of Legal Base and the Common Commercial Policy under the Treaty of Lisbon, pp. 678-694.; TIETJE, C.: Die Außenwirtschaftsverfassung der EU nach dem Vertrag von Lissabon. In: Beitrage zum Internationalen Wirtschaftsrecht. Heft 83. Halle: Universität Halle-Wittenberg, 2009.

2 The "values-driven trade policy" is recent issue in the international trade law circles, predominantly in the USA, however the discussion is focusing on the policy issue itself, and not at all on its axiological, sociological context. (The discussion 
'Europeanisation.' In other terms, Europeanisation is a converging tendency ${ }^{3}$ of third countries' legal order to the EU law. Europeanisation plays, however, also the role of an evocative term, since it can recall the permanent expansion of the legislative and rule-making procedures of the $\mathrm{EU}$ and refers to consequent fact that more and more areas of law have been becoming progressively subject to EU legislative procedures in the last decades. Thus, the evolving process of Europeanisation requires more convergence at domestic level and attempts to minimize the diverging elements of the legal orders, therefore the Member States face increasing level of legal sources, which originate from the EU law and should be adapted and implemented at domestic level. Even though the trends of divergence and convergence and the Europeanization are commonly used and well established in the political science $^{5}$ (and fall partly within the scope of the economics), this paper will not contextualise the insights of these disciplines, but it makes attempt to contribute only to the legal scholarship. The paper, first, lays down the conceptual background, and second, the analysis will highlight a specific example of Europeanisation process taking place in the EU human rights promotion towards third countries.

\section{VALUES AND OTHER RELEVANT CONCEPTS OF THE COMMON COMMERCIAL POLICY}

In the light of the current constitutional structure of the European Union, the formulation and implementation of the CCP, as an integrated part of the Union's external action, are guided by three major categories: values, principles, and objectives. It is worth limiting and clarifying the three concepts at hand briefly.

\subsection{Values}

The 'values' are appearing in Article $2 \mathrm{TEU},{ }^{6}$ declaring that "[ $\left.\mathrm{t}\right]$ he Union is founded on the values of respect for human dignity, freedom, democracy, equality, the rule of law and respect for human rights, including the rights of persons belonging to minorities [...]." These values are common to the

was triggered in February 2014, when the U.S. Trade Representative, Michael Froman delivered a speech on the US postcrisis trade strategy, and brought non-trade issues, as 'values' into prominence. See FROMAN, M.: A Values-Driven Trade Policy. Speech of U.S. Trade Representative Michael Froman of February 18, 2014. Available at: http://cdn.americanprogress.org/wp-content/uploads/2014/02/Center-for-American-Progress-Remarks-Ambassador-Froman-2-18-14.pdf.

3 In other words, the basic concept are based on their original meaning; for similar approach, see LEGRAND, P.: Public Law, Europeanisation, and Convergence: Can Comparatists Contribute? In: BEAUMONT, P. and others (eds.): Convergence and Divergence in European Public Law. Oxford: Oxford University Press, 2002, pp. 225-226.

4 Similarly, 'Europeanization' is meant restricted geographically to EU integration: LEGRAND, P.: Public Law, Europeanisation, and Convergence: Can Comparatists Contribute?, p. 225.

5 For definitions see especially, BÖRZEL, T.: Europeanization: How the European Union Interacts with its Member States. In: BULMER, S. and others (eds): The Member States of the European Union. Oxford: Oxford University Press, 2005, pp. 45-76.

6 Previously, the TEU put emphasis on the 'common values' of the Union, as a specific objective of the Common Foreign and Security Policy ("The Union shall define and implement a common foreign and security policy covering all areas of foreign and security policy, the objectives of which shall be [...] to safeguard the common values, fundamental interests, independence and integrity of the Union in conformity with the principles of the United Nations Charter." Article 11 TEU as amended by the Treaty of Nice). The current text of Article 2 TEU was originally formulated by the European Convention (see Article I-2 of Treaty establishing a Constitution for Europe), which was incorporated into the Treaty of Lisbon later. 
Member States in a society in which pluralism, non-discrimination, tolerance, justice, solidarity and equality between women and men prevail. ${ }^{7}$ In the proper sense of this formulation, the 'values' are expressing the consensual wish of the Member States to submit the whole construction and operation of the Union under these ultimate criteria, representing a community of values. ${ }^{8}$ In other terms, the 'values' can be regarded as fundamental orientations and expectations, which are common, as well as are of a significant nature in the European societies.

However, it is questionable, whether Article 2 TEU does have a sort of meta-legal nature, or it possesses normative quality. ${ }^{9}$ On the one hand, the positioning of the values in the whole structure of the founding treaties suggests, the respect and implementation of values are a conditio sine qua non of the EU membership in accordance with Article 49 TEU. ${ }^{10}$ On the other hand, several specific Treaty provisions are referring to the values, or incorporate it into principles, or Treaty objectives. Accordingly, the provisions of the Treaty oblige the Union, or the Union's institutions to 'promote', to 'uphold', to 'safeguard', to 'protect', to 'assert' the values, ${ }^{11}$ and addresses also the Member States, which are risking possible sanctions in case of serious and persistent breach of the fundamental values of the European Union. ${ }^{12}$ Interestingly, the Treaty makes reference in context of the external relations to the same six 'values' as 'principles', and the promotion, upholding etc. of these values in international relations are set down as 'objective' as well. ${ }^{13}$ In view of the previous reasons, it seems to be plausible, that the listing of values in Article 2 TEU itself has not distinctive character, neither within general scope, nor in context with the external relations and CCP. However, the Treaty lays down legal obligations, when the 'values' are contextualized within more specific principles, the promotion of which is set as an objective of the European Union. In other words, the distinction between the abstract values and the principles seems to be quite elusive, and from this perspective, the values, without denying its fundamental role in the structure of the founding Treaties, might have rather axiological, than legal nature.

Article 2 TEU, second sentence.

8 The concept of 'Union of interest' is rather a political category, which is frequently praised in the literature regarding the European identity. However, the legal scholarship (predominantly the German literature) brings the category of Community of Values (Wertegemeinschaft) into the context of the constitutionalisation process of the European Union. See RENSMANN, T.: Grundwerte im Prozeß der europäischen Konstitutionalisierung. Anmerkungen zur Europäischen Union als Wertegemeinschaft aus juristischer Perspektive. In: BLUMENWITZ, D. and others (eds.): Die Europäische Union als Wertegemeinschaft. Berlin: Duncker \& Humblot, 2005, pp. 49-71.

9 Moreover, it is worth paying attention to the background and the history of origin of the text of Article 2. In light of the explanatory note of the Praesidium of the European Convention, which formulated the original text in 2003, this provision contains only a hard core of values. On the one hand, these values are "[...] fundamental that they lie at the very heart of a peaceful society practising tolerance, justice and solidarity; on the other hand, they must have a clear noncontroversial legal basis so that the Member States can discern the obligations resulting therefrom which are subject to sanction." CONV 528/03. Draft of Articles 1 to 16 of the Constitutional Treaty (6 February 2003), 11. http://europeanconvention.europa.eu/pdf/reg/en/03/cv00/cv00528.en03.pdf

10 Pursuant to Article $49 \mathrm{TEU}$, any European state which respects the values and is committed to promoting them may apply to become a member of the Union.

11 See Article 3 (1), Article 3 (5), Article 13 (1), Article 8, Article 21 (2), and Article 42 TEU.

12 Article 7 TEU.

13 E.g., the values of Article 2 TEU are shown up in Article 21 TEU as 'principles.' The other striking example can be found in the preamble of the Charter of Fundamental Rights of the European Union that seems to be not fully compatible with the wording of Article 2 TEU. In the Charter's preamble, the human dignity, freedom, equality and solidarity are cited as 'universal values', however it refers to the "principles of democracy and the rule of law." 
${ }^{14}$ Disregarding the axiological significance of the values, this all means that the same orientation can be formulated as value and as a principle, which is depending mainly on the wish of the legislator. ${ }^{15}$

\subsection{Principles}

Similarly to the values, the 'principles' are expressing orientations and requirements; however the nature of principles are less abstract and more concrete, than the concept of values is. The principles have normative quality, and in addition to that, are helpful tools in interpretation and legal argumentation. It covers also the general principles developed by the Court of Justice of the European Union inspired by the general rules, objectives, principles laid down in the treaties; common constitutional traditions of the Member States, or international agreements concluded by all Member States. The 'interpretative activism' of the Court led to recognition of several general principles of EU law, which have been made explicit and incorporated into the founding Treaties as 'principles', or as 'values. ${ }^{16}$ Even though the principles encompass more concrete content than the values, the level of abstraction of the principles is variable. Some principles cover larger EU activities (e.g. principles of EU external actions in Article 21 TEU), and other determine specific policy fields (e.g. principles of CCP in Article 207 TFEU).

The proper principles of the EU external relations are enshrined in Article 21 (1) TEU that the European Union "seeks to advance in the wider world." ${ }^{17}$ The Article highlights the below principles of the EU external relations in the following order:

- democracy;

- rule of law;

- universality and indivisibility of human rights and fundamental freedoms;

- human dignity;

- principles of equality and solidarity;

- respect for the principles of the United Nations Charter and international law.

These principles are based partly on the values, however, it cannot be passed over, that the emphasis, e.g. the order of the listing is not identical to the values laid down in Article 2 TEU. In addi-

14 Bogdandy presumes, that even Article 2 TEU refers to 'values', we have to regard these categories as normative provisions and the values as indicated in Article 2 are, in fact, identical to principles. Bogdandy does not deny the distinction between constitutional values and principles, however he does not overlook the dual character of values in Article 2, namely that the same values are present in other places in the Treaty and playing also normative roles (e.g. in Article 3 as objective). See BOGDANDY, A.: Grundprinzipien. In: BOGDANDY, A. - BAST, J.: Europäisches Verfassungsrecht: Theoretische und dogmatische Grundzüge. Berlin: Springer-Lehrbuch, 2009, pp. 13-71, specifically at pp. 28-29.

15 See below the objectives of the Articles 3 and 21 TEU. It is deemed in the literature that the reference to the 'values' is to be understood as something that cannot be reduced to the notion of legal principle, but it maintains an axiological nature, despite the fact that it is found in the text of the Treaty. See BLANKE, H-J. - MANGIAMELI, S. (eds.): The Treaty on European Union (TEU). A Commentary. Wien: Springer, 2013, p. 116, note 26.

16 The Court's case law offers several examples, e.g. the principles related to the rule of law has been recognized even before the founding treaties made any reference to these principles (e.g. 169/80. Administration des douanes v. Société anonyme Gondrand Frères), or as standard example, the Court's rulings on fundamental rights can be highlighted as well (e.g. 9/74. Casagrande v. Landeshauptstadt München; 44/79. Hauer v. Land Rheinland-Pfalz, 36/75. Rutili v. Ministre de l'intérieur, C-159/90 Society for the Protection of Unborn Children Ireland v. Grogan et a., etc.).

17 Article 21 (1) TEU: "The Union's action on the international scene shall be guided by the principles which have inspired its own creation, development and enlargement, and which it seeks to advance in the wider world: democracy, the rule of law, the universality and indivisibility of human rights and fundamental freedoms, respect for human dignity, the principles of equality and solidarity, and respect for the principles of the United Nations Charter and international law." 
tion to the different listing order, Article 21 (1) TEU does not give emphasis neither to the 'freedom', nor to the 'rights of persons belonging to minorities', however, it highlights a specific aspect of human rights ('universality and indivisibility'), and adds to that 'fundamental freedoms', and makes mention of the 'respect for the principles of the United Nations Charter and international law, and of 'solidarity' as well (although the solidarity is not a component of the six fundamental values, it is also included into the second sentence of Article 2 TEU).

If we accept the conclusion of the above analysis of the character of values, namely that the principles put the values into legal context, more precisely, in the legal context of the EU external relations, these differences can be well explicable. From this perspective, e.g. the 'freedom' is too abstract category (the degree of its abstraction is much higher, than the democracy, or human rights etc.), therefore it would have been hardly contextualized within the EU external relations. The emphasis of the universal and indivisible characteristics of human rights, or at least its universality, and the reference to the principles of the United Nations Charter and international law might be well explained in the same way, namely by the fact that the values are here incorporated into the dimension of the international relations. Finally, it is also notable, that the formulation of the paragraph implicitly covers the EU's commitment to promote these values towards third countries, as the EU "seeks to advance" these principles in the "wider world." ${ }^{18}$ In other terms, these principles (in fact, the inherent values) establish not only a general guiding function to the Union's action, but it requires the EU to share these values with the "wider world," underpinning e.g. the human rights conditionality in trade policy vis-à-vis the developing countries. ${ }^{19}$

\section{$2.3 \quad$ Objectives}

The values and the principles have to be distinguished from the category of 'objectives.' The Treaty objectives can take various forms, ${ }^{20}$ and express aims, goals and intentions of the Union, the Union's institutions or the Member States. Having recourse to analogy, the objectives can be regarded as some sort of supranational raison d'État (reasons, objectives of the state). Even though this comparison might not be fully appropriate, the Treaty objectives set the main direction of the Union's actions in a similar way to the reasons of state that also determine the fundamental objectives of a state. Moreover, the Treaty objectives played an important role to define the limits and the content of the Community competences, which was a consequence of the Community model based on a functional integration and the principle of conferral of powers. This function of the objectives was more apparent in the pre-Lisbon era, specifically in the field of the external relations, because the founding treaties did not clarify the division of competences between the European Union and Member

18 For this reason, this commitment is called 'missionary principle' in the literature, see BROBERG, M.: What is the Direction for the EU's Development Cooperation After Lisbon? In: European Foreign Affairs Review, 2011/4, p. 539.; BROBERG, M.: Don't Mess with the Missionary Man! On the Principle of Coherence, the Missionary Principle and the European Union's Development Policy. In: CARDWELL, P. J. (ed.): EU External Relations Law and Policy in the PostLisbon Era. Wien: Springer, 2012, pp. 181-198.

19 See CREMONA, C.: A Constitutional Basis for Effective External Action? An assessment of the Provisions on EU External Action in the Constitutional Treaty. In: EUI Working Papers no. 2006/30, p. 30.

20 The Article 2 of TEC (as amended by the Treaty of Nice) referred to the 'tasks' of the Community (" [...] The Community shall have as its task [...]"), even though the article implies provisions maintaining nature of objectives or goals. The Article 4 TEC conformed to this assumption, when made a reference back to the previous provision as "[...] purposes set out in Article 2". 
States. ${ }^{21}$ The Treaty objectives helped the Court shape the borders of the Community's action, i.e. the objective of liberalization constantly provided the basis for justification in the Court's argumentation, when competence conflicts had to be resolved. Therefore, the most important function of the EU Treaty objectives is to give a tool in the interpretation and in removing the gaps in the EU law. ${ }^{22}$

As mentioned above, the relevant objectives of the external relations are set down in two parts of the Treaty. As a part of the general Treaty objectives, Article 3 (5) TEU are underlining a number of objectives, which the European Union "[i]n its relations with the wider world" has to "uphold and promote", or "shall contribute" to. The relevant objectives are as follows:

- upholding and promoting values and interests of the EU;

- protection of the EU citizens;

- peace;

- security;

- the sustainable development of the Earth;

- solidarity and mutual respect among peoples;

- free and fair trade;

- eradication of poverty;

- protection of human rights, in particular the rights of the child;

- the strict observance and the development of international law, including respect for the principles of the United Nations Charter.

The second layer of the objectives is specified in the general provisions of the Union's external actions. According to the Article 21 (2) TEU, the EU “[...] shall define and pursue common policies and actions, and shall work for a high degree of cooperation in all fields of international relations $[\ldots]$ " with the purpose of realizing the following objectives:

- safeguard its values, fundamental interests, security, independence, and integrity;

- consolidate and support democracy, the rule of law, human rights and the principles of international law;

- preserve peace, prevent conflicts and strengthen international security, in accordance with the purposes and principles of the United Nations Charter, with the principles of the Helsinki Final Act and with the aims of the Charter of Paris, including those relating to external borders;

- foster the sustainable economic, social and environmental development of developing countries, with the primary aim of eradicating poverty;

- encourage the integration of all countries into the world economy, including through the progressive abolition of restrictions on international trade;

- help develop international measures to preserve and improve the quality of the environment and the sustainable management of global natural resources, in order to ensure sustainable development;

21 Not only the exclusive competence character of the Common Commercial Policy was disputed, but also the material extent of the trade policy, i.e. how can the Community's competence go beyond the international trade in goods, and involve the regulatory field of services, commercial aspects of IP rights etc.

22 The functions of the Treaty objectives are systematically analysed by Reimer, distinguishing between meta-legal and legal functions. The first category encompasses the informative function and the function of integration. The components of the second category are the competence extending function, referring function, regulatory function, and the specific role suggesting that that function can be considered as a standard of the Community's activity. REIMER, F.: Ziele und Zuständigkeiten. Die Funktionen der Unionszielbestimmungen. In: Europarecht, 2003/6, pp. 992-1012. For detailed analysis of the Treaty objectives, see MÜLLER-GRAFF, P.-C.: Lissabonner Umwertung oder Kontinuität der EU-Vertragsziele? In: Festschrift 50 Jahre ZfRV. 2013, pp. 139-153. 
- assist populations, countries, and regions confronting natural or man-made disasters;

- promote an international system based on stronger multilateral cooperation and good global governance.

Even if this listing is not new - for the most part, they are rooted in previous Treaty provisions ${ }^{23}$ -, it is significant, that these objectives are aiming to determine and influence horizontally the specific fields of external relations, including the CCP. Even a quick reading of the objectives listed in these Articles uncovers more overlapping components, not only within the objectives, but in relation to the principles as well. Due to its complexity, the deep analysis of all objectives is unrealizable within the framework of this paper, ${ }^{24}$ however, it is questionable, how these objectives do relate to the external trade policy, more specifically how it may imply the objective of liberalization of the CCP, since both Article 3 (5) and Article 21 (2) TEU refer to objectives, which can shape the content and interpretation of liberalization objective of the CCP.

\subsection{Consistency requirement}

The question is still to be answered, how the principles and objectives of general and specific levels are relating to each other. Earlier, the possible conflict between the trade-related objectives and general objectives could be resolved by the specificity of the trade policy, i.e. the goals of the CCP, as lex specialis, was deemed to prevail over the general objectives of the Community. ${ }^{25}$ Later, the Single European Act introduced a requirement for coherence and consistency within the external Community policies, stipulating that "the external policies of the EC and the policies agreed in European Political Cooperation must be consistent." Moreover it has referred also to the institutional aspect of consistency, as stated that "the Presidency and the Commission, each within its own sphere of competence, shall have special responsibility for ensuring that such consistency is sought and maintained." 26

The Treaty of Lisbon applied the same method and added the consistency requirement to the unified structure of external objectives and principles, ensuring the consistency of general and specific, trade-related principles and objectives. The consistency requirement is reinforced by institutional cooperation as well, obliging the key players of external action: the Council and the Commission, assisted by the High Representative for Foreign Affairs and Security Policy, who have to cooperate in order to ensure this consistency. ${ }^{27}$ The consistency requirement is still handled more

23 See the former Article 11 TEU Paragraph 1 (as amended by the Treaty of Nice), and specifically, Articles 131, 174, and 177 in the TEC.

24 See detailed commentary for the principles: GRABITZ, E. and others (eds.): Das Recht der Europäischen Union. Art. 21 TEU. München: C.H. Beck, 2011; BLANKE, H-J. - MANGIAMELI, S.: The Treaty on European Union (TEU). A Commentary, pp. 831-910.

25 In context with the pre-Lisbon structure of founding treaties, Basedow made reference to the principle of lex specialis derogat legi generali: BASEDOW, J.: Zielkonflikte und Zielhierarchien im Vertrag über die Europäische Gemeinschaft. In: Due and others (eds.): Festschrift für Ulrich Everling. Baden-Baden: Nomos, 1995, p. 51. Contrary to this view, the TEU commentary of Blanke - Mangiameli highlights the equal status of the Treaties after Lisbon pursuant to Article $1 \mathrm{TEU}$, consequently, neither the rule of lex superior derogat legi inferiori nor the rule of lex posterior derogat legi priori may apply. See BLANKE, H-J. - MANGIAMELI, S.: The Treaty on European Union (TEU). A Commentary, p. 87.

26 Single European Act (OJ L 169, 29. 6.1987), Article 30 (5). Similarly, the preamble of the SEA gave emphasis to the consistency: "Aware of the responsibility incumbent upon Europe to aim at speaking ever increasingly with one voice and to act with consistency and solidarity in order more effectively to protect its common interests and independence [...]" Single European Act, preamble, fifth recital.

27 Article 21 (3) TEU: "[...] The Union shall ensure consistency between the different areas of its external action and be- 
clearly on the level of the CCP (and other external policies laid down in the TFEU), because the provisions of Article $21 \mathrm{TEU}$ on consistency is repeated in Article $205 \mathrm{TFEU} .{ }^{28}$ In addition, the reference to the principles and objectives of Union's external action is stressed - unnecessarily again - in Article 207 TFEU. $^{29}$

According to the grammatical and systematic interpretation of these provisions it is plausible that the inherent principles and objectives of CCP governed by free trade ideas are not strictly subordinate to the general principles of external relations, but the EU trade policy should be 'guided' by the principles and objectives of general level. In other terms, the EU, at least, has to take into account these concepts, which encompass a sort of non-economic and non-trade factors. ${ }^{30}$ In the subsequent chapter, the inclusion of the human rights is highlighted within a short analysis.

\section{$3 \quad$ PROMOTING VALUES IN THIRD COUNTRIES - THE EXAMPLE OF THE HUMAN RIGHTS}

Originally the external trade and development policy of the European Community was predominantly driven by economic and commercial factors. The trade and human rights nexus in these external policies has become palpable in the 1970s, and particularly the 'Uganda-crisis' brought the human rights conditionality to the Community's trade agenda. ${ }^{31}$ Uganda was contracting party of the Lomé Convention concluded by the Community with African, Caribbean and Pacific group of states with the purpose of laying down the framework of trading relations and providing supporting to these countries. In line with the Stabex system covered by this agreement, Uganda was provided supports of different art (concessions, trade incentives, humanitarian support etc.). However, this support has been suspended in the year of 1977 as a response to the human right violations committed by the governing regime, which came to power by a military coup d'etat in 1971. The suspension was initiated by the European Parliament, ${ }^{32}$ which political initiative was later accepted by the European Commission, reinforced by a Council Declaration. ${ }^{33}$ The Council Declaration - called also as 'Uganda Guidelines' - made evident the basic layout of the conditional policy, namely, no support or concession could be provided to a country, when the supports could help the ruling governments to maintain their power including the suppression and human right violations against their population. From technical point of view, the Declaration has not ceased the Lomé Convention vis-á-vis Uganda,

tween these and its other policies. The Council and the Commission, assisted by the High Representative of the Union for Foreign Affairs and Security Policy, shall ensure that consistency and shall cooperate to that effect."

28 Cf. with Article 205 TFEU.

29 Article 207 TFEU paragraph 2: „The Common Commercial Policy shall be conducted in the context of the principles and objectives of the Union's external action."

30 Tietje regards that as 'politisation' of the CCP and makes some critics on that, see TIETJE, C.: Die Außenwirtschaftsverfassung der EU nach dem Vertrag von Lissabon. Beitrage zum Internationalen Wirtschaftsrecht, p. 20.

31 See BARTELS, L.: The Trade and Development Policy of the European Union. In: European Journal of International Law, 2007/4, p. 737.

32 ARTS, K.: Integrating Human Rights into Development Cooperation: The Case of the Lomé Convention. Hague: Martinus Nijhoff Publishers, 2000, p. 322.

33 Council Declaration on the situation in Uganda (21 June 1977) Bulletin of the European Communities, 6-1977. para 2.2.59. 
but the application of the Convention has resulted in a de facto suspension concerning Uganda. ${ }^{34}$ In other terms, the Uganda affaire introduced the policy of the human rights conditionality in the field of the EC external trade and development policy and clearly manifested that the EC was committed to include the human rights into its external trade relations.

This policy later influenced also the content and conclusion of agreements in this field. Even the third Lomé Convention referred to human rights as principles, ${ }^{35}$ and the first human rights clause was integrated in the fourth Lomé Convention concluded with the ACP countries in 1989. The formulation of the human rights clause has been shaped later, and the Commission made efforts to include these clauses as standard elements into the EC agreements. In doing so, the Commission adopted a communication in $1991^{36}$ that led to a Council decision, which stressed the importance of the application of human rights clauses in this field. ${ }^{37}$ Following the Council decision, the EC/ EU has always put in the negotiation agenda several types of agreements, including development, association, or partnership agreements and applied the clauses in more 'style forms' (e.g. ,Baltic Clauses', ,Bulgarian Clauses' etc.). After 1995, the EU attempted to standardise the rules to be integrated as 'essential elements clause.' This standardisation did not mean totally uniform contents, since the negotiations was conducted always in a tailor-made approach, however the clauses applied had common features and standard elements. Principally, the clause is based on positive incentives (e.g. trade preferences) coupled with general objectives, e.g. cooperation, dialogue and transparency, good governance etc., and at the same way, is linked to negative consequences in case of breach or non-fulfilment of the requirements laid down and specified separately (non-execution clause). The clause itself is composed of four main elements:

- emphasising the importance of respect of human rights, democratic principles etc.;

- it usually cites important relevant international law, sources, documents, conventions to be taken into consideration;

- stating how the agreement underpins inner and international policies;

- and finally, the clause stressed out that it constitutes an essential element of the treaty.

In addition to the essential elements clause, the non-execution clause can be regarded as guarantee of the human rights requirements, describing the possible consequences of the breach of these essential parts of the agreements. The EU has been always a dominant promoter of the inclusion of social policy concerns into the external trade policy, which approach has been continued subsequently. After adopting the Global Europe Strategy in 2006, ${ }^{38}$ the European Commission is intending to conclude new generation of free trade agreements with emerging markets, which go already beyond the 'classic' free trade agreements, including not only rule of law and human rights clauses, but also environmental objectives, and sustainable development. Moreover, it is worth noting, however, that this inclusive approach of the EU is not only a part of the policy agenda towards

34 ARTS, K.: Integrating Human Rights into Development Cooperation: The Case of the Lomé Convention, p. 323.

35 Ibid., p. 329

36 Human Rights, Democracy and Development Cooperation Policy. Commission Communication to the Council and Parliament. SEC(91) 61 final. 25 March 1991.

37 Resolution of the Council and of the Member States meeting in the Council on human rights, democracy and development. 28 November 1991. Bulletin of the European Communities, 11 1991. para. 122-3

38 The strategy emphasised, that the new free trade agreements concluded by the EU, should include "new co-operative provisions relating to labour standards and environmental protection." These combined clauses are standard component in the FTAs today. See Global Europe - Competing in the world. A contribution to the EUs Growth and Job Strategy, COM (2006) 567., p. 12. 
the developing countries. Even the recent trade and investment partnership agreements, such as 'mega-regionals' (e.g. CETA or TTIP), aim at integrating several non-trade concerns including the principles of human rights into the body of the agreements.

\section{CONCLUSION}

Since the Treaty of Lisbon introduced the unified concept of EU external action, the above mentioned concerns should be integrated into the agreements concluded by the EU with third countries, which can have implications on the third countries' legal order as well. This process of Europeanisation and specific approach can signalise that the Walter Hallstein's concept on Community of Law ("Rechtsgemeinschaft") is even developing, and also a Community of Values ("Wertegemeinschaft") is emerging and has become the centre of action of the European Union external action. However, as the above analysis has shown, the values and other relevant constitutional concepts are forming a colourful set of categories, which are sometimes of contrasting nature. In other terms, if several principles and objectives are incorporated in a systematic order, the question concerning the potential conflicts between the different areas, principles and objectives might always arise. This issue is specifically relevant now, because the Treaty of Lisbon has inserted several principles and objectives which could be hardly reconciled with the logic of the trade policy and principally with the objective of liberalisation. Therefore, conflict or tensions can be expected in the relation of trade and non-trade concerns, e.g. in issues of the above examined trade and human rights, trade and environment, trade and labour rights and social policy concerns, etc. It is notable, from this perspective, that these topics have significance not only at the level of the European Union, but also in the field of international trade law, namely within the World Trade Organization. The core argument of the debate behind these potential tensions focuses on the fact that the abolition of trade barriers may not have only beneficial impacts. However, the harmful implications caused by the liberalisation most often come up not in the field of trade but areas of other social dimensions can be negatively affected. Therefore, it is highly important to put the values incorporating social policy concerns into the external trade agenda of the European Union.

\section{Bibliography:}

ARTS, K.: Integrating Human Rights into Development Cooperation: The Case of the Lomé Convention. Hague: Martinus Nijhoff Publishers, 2000.

BARTELS, L.: The Trade and Development Policy of the European Union. In: European Journal of International Law, $2007 / 4$.

BASEDOW, J.: Zielkonflikte und Zielhierarchien im Vertrag über die Europäische Gemeinschaft. In: Due and others (eds.): Festschrift für Ulrich Everling. Baden-Baden: Nomos, 1995.

BLANKE, H-J. - MANGIAMELI, S. (eds.): The Treaty on European Union (TEU). A Commentary. Wien: Springer, 2013.

BOGDANDY, A.: Grundprinzipien. In: BOGDANDY, A. - BAST, J.: Europäisches Verfassungsrecht: Theoretische und dogmatische Grundzüge. Berlin: Springer-Lehrbuch, 2009, pp. 13-71. 
BÖRZEL, T.: Europeanization: How the European Union Interacts with its Member States. In: BULMER, S. and others (eds): The Member States of the European Union. Oxford: Oxford University Press, 2005, pp. 45-76.

BROBERG, M.: Don't Mess with the Missionary Man! On the Principle of Coherence, the Missionary Principle and the European Union's Development Policy. In: CARDWELL, P. J. (ed.): EU External Relations Law and Policy in the Post-Lisbon Era. Wien: Springer, 2012, pp. 181-198.

BROBERG, M.: What is the Direction for the EU's Development Cooperation After Lisbon? In: European Foreign Affairs Review, 2011/4, pp. 539-557.

BUNGENBERG, M. - HERRMANN, C. (eds.): Common Commercial Policy after Lisbon. In: European Yearbook of International Economic Law, Special issue, 2013.

CREMONA, C.: A Constitutional Basis for Effective External Action? An assessment of the Provisions on EU External Action in the Constitutional Treaty. In: EUI Working Papers no. 2006/30.

CREMONA, M.: Balancing Union and Member State interests: Opinion 1/2008, Choice of Legal Base and the Common Commercial Policy under the Treaty of Lisbon. In: European Law Review, 35, 2010/5., pp. 678-694.

DIMOPOULOS, A.: The common commercial policy after Lisbon: Establishing parallelism between internal and external economic relations? In: Croatian Yearbook of European Law and Policy, 2008/4, pp. 101-129.

FROMAN, M.: A Values-Driven Trade Policy. Speech of U.S. Trade Representative Michael Froman of February 18, 2014. Available at: http://cdn.americanprogress.org/wp-content/uploads/2014/02/Center-for-American-ProgressRemarks-Ambassador-Froman-2-18-14.pdf

GRABITZ, E. and others (eds.): Das Recht der Europäischen Union. Art. 21 TEU. München: C.H. Beck, 2011.

KRAJEWSKI, M.: The Reform of the Common Commercial Policy. In Biondi A. and others (eds.): EU Law after Lisbon. Oxford: Oxford University Press, 2012, pp. 292-311.

LEGRAND, P.: Public Law, Europeanisation, and Convergence: Can Comparatists Contribute? In: BEAUMONT, P. and others (eds.): Convergence and Divergence in European Public Law. Oxford: Oxford University Press, 2002, pp. 225-226.

MÜLLER-GRAFF, P.-C.: Lissabonner Umwertung oder Kontinuität der EU-Vertragsziele? In: Festschrift 50 Jahre ZfRV. 2013, pp. 139-153.

REIMER, F.: Ziele und Zuständigkeiten. Die Funktionen der Unionszielbestimmungen. In: Europarecht, 2003/6, pp. 992-1012.

RENSMANN, T.: Grundwerte im Prozeß der europäischen Konstitutionalisierung. Anmerkungen zur Europäischen Union als Wertegemeinschaft aus juristischer Perspektive. In: BLUMENWITZ, D. and others (eds.): Die Europäische Union als Wertegemeinschaft. Berlin: Duncker \& Humblot, 2005, pp. 49-71.

TIETJE, C.: Die Außenwirtschaftsverfassung der EU nach dem Vertrag von Lissabon. In: Beitrage zum Internationalen Wirtschaftsrecht. Heft 83. Halle: Universität Halle-Wittenberg, 2009.

\section{Contact information:}

Dr. Balazs Horvathy PhD

horvathy.balazs@tk.mta.hu

HAS Centre for Social Sciences Institute for Legal Studies

H-1014 Budapest

Orszaghaz utca 30.

Hungary 